\title{
PERANAN PASUKAN CAWANGAN KHAS POLIS DIRAJA MALAYSIA (PDRM) DALAM MENANGANI ANCAMAN KOMUNIS, 1968-1989
}

\author{
Amer Fawwaz Mohamad Yasid
}

\begin{abstract}
Malaysia was one of the countries that faced the security threat of communist insurgency; inflicted by the Communist Party of Malaya (CPM) since 1948. Although having been defeated by the Malayan Security Forces in 1960, the CPM took their second opportunity by reviving their armed struggle, prompting the Second Malaysia Emergency in 1968 which lasted for almost 40 years. The success of the Malaysian Security Forces in the Second Emergency was based on meticulous implementation of intelligence services by the Royal Malaysian Police Special Branch (SB) Division, known for their high reputation and efficiency in counter-intelligence in the 1970s. This study focuses on the roles and functions of the Special Branch, primarily its intelligence strategies and tactics, which led to the defeat of the CPM in 1989.
\end{abstract}

\section{Pengenalan}

Malaysia adalah salah sebuah daripada negara di dunia yang menghadapi ancaman Insurgensi Komunis selepas Perang Dunia Kedua terutamanya apabila rantau Asia Tenggara telah menjadi sasaran kepada Kesatuan Komunis Soviet Union untuk meluaskan lagi empayar mereka ke serata dunia ketika awal Perang Dingin. Pada tahun 1948, Parti Komunis Malaya (PKM) yang diketuai oleh Chin Peng telah melancarkan serangan ke seluruh Semenanjung Tanah Melayu bagi mengambil alih kuasa pemerintahan Kerajaan British di Tanah Melayu bersandarkan prinsip "Kekuasaan Politik Lahir Daripada Laras Senapang" yang telah diagungkan oleh pemimpin komunis China, iaitu Mao Tse Tung. ${ }^{1}$

Walau bagaimanapun, usaha PKM telah gagal dalam melancarkan pemberontakan bersenjata mereka dengan berkat usaha dan peranan pasukan keselamatan yang dimainkan oleh pasukan tentera dan Tanah Melayu pada ketika itu. Salah satu faktor yang memberikan kemenangan kepada pasukan keselamatan di Malaya adalah hasil daripada idea British untuk menubuhkan sebuah unit yang berperanan sebagai penyalur maklumat perisikan yang diterajui oleh Pasukan Polis Persekutuan Malaya yang dinamakan sebagai Cawangan Khas ataupun lebih dikenali sebagai Special Branch. Pasukan Cawangan Khas Polis Diraja Malaysia (PDRM) ini ditubuhkan pada tahun $1948^{2}$ dan berperanan sebagai sebuah badan perisikan yang bertanggungjawab dalam menyalurkan maklumat perisikan kepada angkatan tentera British serta pasukan keselamatan ketika Darurat 1948-1960.

Kebanyakan ahli akademik serta sejarawan berpendapat Pasukan Cawangan Khas PDRM telah memainkan peranan yang besar dalam menentukan kejayaan British ketika menghadapi Insurgensi Komunis di Tanah Melayu, antaranya seperti Comber, ${ }^{3}$ Komer, ${ }^{4}$ Short, ${ }^{5}$ Leong, ${ }^{6}$ dan Reduan.7 Pemberontakan bersenjata PKM ketika Darurat 1948-1960 menemui jalan buntu apabila kebanyakan daripada pasukan penggempur PKM serta rejimen utama mereka telah berjaya dimusnahkan oleh pasukan keselamatan melalui tekanan yang lahir daripada kebijaksanaan British serta pasukan keselamatan dalam melaksanakan taktik serta strategi 'cegah-rintang' (counter-insurgency). Akhirnya pada tahun 1960, kerajaan Malaysia telah mengisytiharkan berakhirnya darurat di seluruh negara. 8 Dalam pada itu, sebahagian besar daripada pasukan penggempur PKM serta Ahli Jawatankuasa Pusat PKM telah berundur ke selatan Thailand. Ini adalah bertujuan bagi 
membina semula kekuatan parti mereka setelah mereka ditewaskan oleh pasukan keselamatan. ${ }^{9}$ PKM mengambil masa selama lapan tahun untuk membina semula kekuatan mereka sebelum melancarkan pemberontakan bersenjata bagi kali kedua dan berterusan selama 21 tahun.

Artikel ini akan mengupas peranan yang telah dimainkan oleh Pasukan Cawangan Khas PDRM dalam menangani ancaman bersenjata komunis pada tahun 1968-1989, serta melihat apakah taktik dan strategi yang telah dijalankan oleh Pasukan Cawangan Khas PDRM dalam membendung usaha PKM untuk mendominasi negara ini melalui "laras senapang". Pasukan Cawangan Khas PDRM merupakan salah sebuah organisasi yang masih dianggap sebagai rahsia sehingga kini serta tidak mendapat liputan yang meluas mengenai peranan serta penubuhannya oleh orang ramai. Kebanyakan di antara kita menganggap bahawa peranan yang ditonjolkan oleh Pasukan Cawangan Khas PDRM semata-mata bagi menahan golongan kiri serta reformis yang mengancam keselamatan negara. Akan tetapi tugas serta bidang yang telah ditonjolkan oleh Pasukan Cawangan Khas PDRM lebih besar daripada apa yang digembar-gemburkan oleh pandangan umum masyarakat pada hari ini.

\section{Struktur Organisasi Pasukan Cawangan Khas PDRM}

Pasukan Cawangan Khas PDRM telah ditubuhkan sejak tahun 1948 dan peranannya sebagai sebuah agensi perisikan ketika Darurat 1948-1960, tidak dapat dinafikan keberkesananya serta reputasi yang tinggi dalam menghapuskan ancaman komunis pada ketika itu. Walau bagaimanapun, struktur organisasi serta peranan yang ditonjolkan oleh Pasukan Cawangan Khas PDRM telah menjadi lebih besar selaras dengan ancaman bersenjata yang telah ditunjukkan oleh PKM ketika Darurat 1968-1989. Pasukan Cawangan Khas PDRM secara amnya dikenali sebagai Unit Divisyen "E". ${ }^{10}$ Pasukan ini diketuai oleh seorang Pengarah Cawangan Khas berpangkat Timbalan Pesuruhjaya Polis (Deputy Comissioner of Police) ${ }^{11}$ serta dibantu oleh seorang Timbalan Pengarah yang berpangkat Penolong Pesuruhjaya Kanan Polis (Senior Assistant Commissioner of Police)12. Di bawah Pasukan Cawangan Khas PDRM, terdapat beberapa buah Jabatan yang telah diperuntukkan bagi meningkatkan lagi kecekapan pasukan dalam menjalankan tugas serta bidang kuasa yang telah ditetapkan. Setiap Jabatan di bawah Cawangan Khas diketuai oleh seorang Pegawai Kanan yang berpangkat Penolong Pesuruhjaya Polis (Assistant Commissioner of Police)..$^{13}$

Rajah 1 dan Jadual 1 menunjukkan carta organisasi serta tugas setiap unit yang terletak di bawah Jabatan Cawangan Khas ketika Darurat 1968-1989. Secara khususnya, struktur organisasi serta perancangan jabatan yang terdapat di bawah Pasukan Cawangan Khas PDRM amatlah sistematik dan teratur menjadikan pasukan ini sangat efisyen dalam memburu serta memusnahkan pertubuhan bawah tanah PKM melalui kegiatan perisikan yang dijalankan oleh anggota-anggota yang bertugas di bawah pasukan tersebut. Kesiap siagaan pasukan dalam menangani ancaman bersenjata PKM berada ditahap yang tinggi apabila setiap jabatan telah menetapkan standard piawaian operasi pasukan yang begitu tinggi ditambah pula dengan program latihan yang dipertingkatkan dari masa ke semasa menjadikan pasukan Cawangan Khas ini berada di tahap yang terbaik. 
Rajah 1: Carta Organisasi Pasukan Cawangan Khas PDRM (1970-1990)14

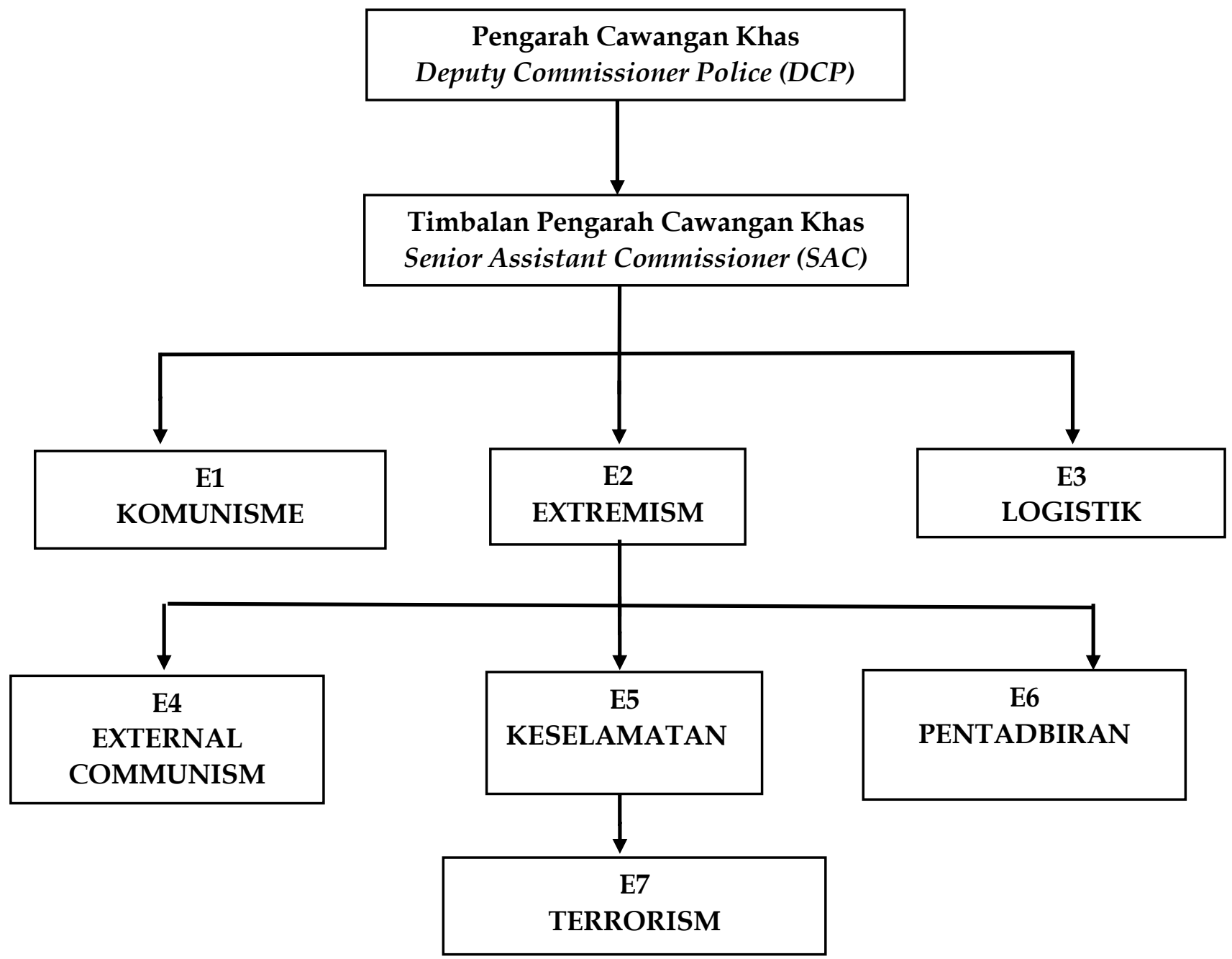

Sumber: Maklumat yang diperoleh daripada Datuk Dr. Leong Chee Woh, Bekas Timbalan Pengarah Cawangan Khas Polis Diraja Malaysia (1981-1984) pada 25 Mei 2015.

Jadual 1: Peranan serta Fungsi Jabatan Yang Terdapat di bawah Pasukan Cawangan Khas PDRM Ketika Darurat, 1970-1990

\begin{tabular}{|l|l|}
\hline \multicolumn{1}{|c|}{ JABATAN } & \multicolumn{1}{c|}{ PERANAN DAN FUNGSI } \\
\hline E1 KOMUNISME & $\begin{array}{l}\text { Unit E1 adalah unit utama di bawah pasukan Cawangan Khas } \\
\text { yang bertanggungjawab terhadap apa-apa aktiviti pergerakan } \\
\text { bawah tanah PKM dalam aspek perlaksanaan operasi cegah } \\
\text { rintang (Counterinsurgency), perlaksanaan operasi anti-perisikan } \\
\text { (Counter-intelligence) terhadap pasukan musuh, proses soal } \\
\text { siasat bagi mendapatkan maklumat risikan yang melibatkan } \\
\text { anggota musuh yang ditawan ataupun menyerah diri (SEP), } \\
\text { serta proses penterjemahan dan analisis dokumen yang } \\
\text { dirampas daripada pihak komunis. }\end{array}$ \\
\hline E2 EXTREMISM & $\begin{array}{l}\text { Unit E2 berperanan dalam menyelia serta memerhatikan apa- } \\
\text { apa pergerakan Pertubuhan mahupun kumpulan ekstrim yang } \\
\text { berpotensi untuk mengancam keselamatan di peringkat }\end{array}$ \\
\hline
\end{tabular}




\begin{tabular}{|c|c|}
\hline & $\begin{array}{l}\text { kebangsaan serta keselamatan dalam negeri seperti: } \\
\text { - Pergerakan kesatuan buruh dan massa yang berhaluan } \\
\text { kiri. } \\
\text { - Parti-parti politik yang berideologi extremism } \\
\text { - Pergerakan pertubuhan pelajar dan mahasiswa. }\end{array}$ \\
\hline E3 LOGISTIK & $\begin{array}{l}\text { Unit E3 pula bertanggungjawab dalam hal ehwal teknikal } \\
\text { seperti proses pemantauan, bantuan, serta pentadbiran teknikal } \\
\text { dalam sesebuah operasi yang dijalankan. }\end{array}$ \\
\hline $\begin{array}{l}\text { E4 EXTERNAL } \\
\text { COMMUNISM }\end{array}$ & $\begin{array}{l}\text { Unit ini adalah unit terpenting dalam pasukan Cawangan Khas } \\
\text { yang bertanggungjawab terhadap kemasukan pengaruh luar } \\
\text { ataupun anasir-anasir komunis yang bertapak di luar negara } \\
\text { dan menyusup masuk ke dalam Malaysia. Antara anasir-anasir } \\
\text { yang dipantau dengan ketat ketika Darurat 1968-1989 adalah } \\
\text { seperti Parti Komunis Indonesia (PKI), Parti Komunis China } \\
\text { (PKC), Parti Komunis Thailand (PKT), Parti Komunis Vietnam } \\
\text { (PKV) dan Parti Komunis Soviet Union (PKSU). Selain daripada } \\
\text { itu, unit ini juga berperanan terhadap hal ehwal Keselamatan } \\
\text { Diplomatik Malaysia di luar negara seperti Kedutaan Besar } \\
\text { Negara, Pejabat Konsulat, dan Pejabat Pesuruhjaya Tinggi, } \\
\text { dengan menempatkan beberapa orang pegawai yang } \\
\text { ditugaskan sebagai Atase Keselamatan. }\end{array}$ \\
\hline E5 KESELAMATAN & $\begin{array}{l}\text { Berperanan sebagai unit yang mengawal selia keselamatan di } \\
\text { pintu masuk serta persempadanan negara yang berkaitan } \\
\text { dengan: } \\
\text { - Lapangan terbang (domestik dan antarabangsa) } \\
\text { - Pasport dan kawalan perjalanan } \\
\text { - Perlindungan keselamatan kenamaan (VIP) sama ada } \\
\text { dalam negara mahupun dari luar negara. }\end{array}$ \\
\hline E6 PENTADBIRAN & $\begin{array}{l}\text { Unit ini bertanggungjawab dalam mengenalpasti ataupun } \\
\text { membuat senarai penting terhadap kawasan operasi pasukan } \\
\text { penggempur PKM yang berkaitan dengan maklumat-maklumat } \\
\text { penting seperti lokasi kubu-kubu serta kem-kem latihan Unit- } \\
\text { pasukan penggempur PKM, senarai nama Ahli-ahli } \\
\text { Jawatankuasa Pusat, Negeri, serta Daerah PKM, senarai nama } \\
\text { komander utama pasukan penggempur PKM, serta } \\
\text { menguruskan perbelanjaan pasukan yang berkaitan dengan hal } \\
\text { ehwal kewangan pasukan, operasi serta alatan persenjataan } \\
\text { yang akan digunakan dalam sesebuah operasi yang bakal } \\
\text { dijalankan. }\end{array}$ \\
\hline E7 TERRORISME & $\begin{array}{l}\text { Unit ini ditugaskan bagi mencegah pergerakan yang bersifat } \\
\text { terorisme ataupun kumpulan keganasan selain daripada } \\
\text { pertubuhan komunis. }\end{array}$ \\
\hline
\end{tabular}

Sumber: Dokumen peribadi Datuk Dr. Leong Chee Woh, Bekas Timbalan Pengarah Cawangan Khas Polis Diraja Malaysia (1981-1984).

\section{Peranan Pasukan Cawangan Khas PDRM Ketika Darurat}

Setelah berundur ke selatan Thailand, PKM telah berusaha secara khusus menumpukan semula usaha-usaha bagi membina kekuatan Parti. Pada masa yang sama, mereka merekrut anak-anak muda di seluruh Semenanjung Malaysia bagi menyertai organisasi bawah tanah yang akan digemblengkan bagi melancarkan pemberontakan bersenjata yang kedua. Usaha 
perkaderan yang dijalankan beroperasi daripada kem-kem latihan yang dibina dalam kawasan hutan di sekitar Betong. 15 Kebanyakan daripada anak-anak muda yang diindoktrinisasikan oleh pihak PKM merupakan anak-anak muda yang berpendidikan daripada sekolah-sekolah Vernakular Cina seperti Methodist, Chung Hwa, Kuen Chen, Tsun Jin, dan Sekolah Cina Confucius. ${ }^{16}$ Pada masa yang sama, organisasi bawah tanah PKM juga turut menggunakan saluran massa melalui pergerakan kesatuan yang bertapak di Semenanjung Malaysia seperti kesatuan buruh, persatuan-persatuan pelajar, kongres sekerja serta parti-parti politik yang berhaluan kiri17 bagi merekrut golongan muda untuk mendapatkan latihan bercorak ketenteraan di selatan Thailand yang merangkumi latihan bersenjata seperti peperangan gerila, taktik peperangan hutan, serang hendap, pembuatan jerangkap samar, gerakan bawah tanah, pembelajaran doktrin komunisme, serta perisikan.18

Latihan-latihan ini dijalankan secara berterusan dengan mendapat tunjuk ajar daripada kader-kader PKM yang didatangkan khas dari negara China. ${ }^{19}$ Sesetengah daripada kader-kader ini pernah mempunyai pengalaman yang meluas dalam peperangan melawan pihak Jepun ketika Perang Manchuria 1936. Justeru latihan yang dijalani oleh anak-anak muda yang menyertai PKM di selatan Thailand telah diajar oleh jurulatih yang sangat profesional dan berpengalaman dalam perang gerila. Beberapa tahun sebelum PKM melancarkan pemberontakan bersenjata untuk kali yang kedua, Jawatankuasa Pusat PKM telah mengarahkan pasukan penggempur PKM untuk membina kem-kem dalam hutan di sekitar kawasan yang baru serta strategik. Walaupun sejumlah besar kem-kem komunis telah dibina ketika Darurat 1948-1960, akan tetapi Jawatankuasa Pusat PKM telah memberikan arahan kepada unit-unit penggempur PKM untuk meninggalkan kem-kem tersebut atas faktor keselamatan bagi mengelakkan lokasi mereka mudah ditemui oleh pasukan keselamatan di masa hadapan. ${ }^{20}$

Pada tahun 1968, Jawatankuasa Pusat PKM telah mengeluarkan arahan bagi melancarkan pemberontakan bersenjata yang kedua melalui petikan ucapan bersempena dengan sambutan Penubuhan PKM yang ke-40 yang berbunyi:

Masyarakat kita terdiri daripada beberapa kaum, terdiri kebanyakannya dari orang-orang Melayu, Cina dan India serta lain-lain kaum yang kecil. Sungguhpun Parti kita semenjak ditubuhkan telah giat bergerak di kalangan rakyat jelata... soal penting menganalisa sama ada tenaga penggerak revolusi dalam negeri ini hendak didasarkan kepada kelas ataupun pada kaum belum diputuskan lagi. Asas pendirian Parti kita dalam tahun 1954 ialah bahawa orang-orang Cina dan India adalah kaum mendatang dan orang-orang Melayu sebagai Bumiputera. Oleh kerana tidak ada suasana yang sesuai untuk mendapatkan kerjasama orang-orang "Melayu" yang kononya suatu tenaga penting, maka tidak dapatlah perjuangan bersenjata diteruskan, dan sekiranya diteruskan perjuangan bersenjata, Parti kita akan membantu Pihak penjajah dengan membangkitkan kekacauan antara kaum... Pada hakikatnya, soal kaum itu jika dianalisa betul-betul adalah sebenarnya soal kelas. Walaupun soal perkauman di Malaya mempunyai ciri-ciri tersendiri akan tetapi jika berdasarkan pada padangan kelas mengikut fahaman Marx dan Lenin serta ajaran-ajaran Mao Tse Tung maka barulah kita dapati kesimpulan yang betul atas soal tenaga penggerak revolusi dalam negeri kita! Oleh yang demikian, PKM secara umumnya telah memberikan hujahhujah yang menegaskan untuk menyokong dasarnya melancarkan pemberontakan bersenjata terus-terusan tanpa memperkirakan akibatnya dari segi perkauman. ${ }^{21}$ 
Pada 1 Jun 1968, pihak PKM telah melancarkan pemberontakan bersenjata mereka apabila unit penggempur mereka telah menyerang sebuah konvoi pasukan keselamatan di Kroh, Pengkalan Hulu yang menyebabkan kematian 16 orang anggota Pasukan Polis Hutan $(\mathrm{PPH}){ }^{22}$ Dengan itu bermulalah detik peranan berat yang dimainkan oleh Pasukan Cawangan Khas PDRM dalam menangani ancaman komunis di Malaysia. Peranan utama yang ditonjolkan oleh pasukan Cawangan Khas adalah bagi mendapatkan dan memberikan maklumat serta info perisikan kepada pasukan keselamatan yang terlibat ketika Darurat 1968-1989 iaitu Tentera Darat Malaysia (TDM) dan Polis Diraja Malaysia (PDRM).23 Perisikan adalah kaedah yang terpenting dalam memastikan bahawa konsep 'cegah-rintang' (counter-insurgency) yang dijalankan berjaya. Ini kerana sumber perisikan berperanan sebagai mata dan telinga kepada pasukan keselamatan bagi mengetahui kedudukan serta kekuatan pasukan musuh.

Secara dasarnya, tugas pengumpulan data perisikan dibahagikan kepada beberapa sektor kerana Pasukan Cawangan Khas PDRM turut bekerjasama dengan Pasukan Perisikan Tentera Darat Malaysia (TDM) dalam menangani ancaman komunis di Malaysia. Sebagai contoh, Pasukan Cawangan Khas PDRM hanya terlibat dalam proses pengumpulan data perisikan terhadap musuh di kawasan bandar hingga ke pinggir hutan, manakala pasukan Perisikan TDM bertanggungjawab untuk menjalankan proses pengumpulan maklumat risikan dalam kawasan tanggungjawab yang kebiasaannya terletak di tengah kawasan hutan yang menjadi tempat pasukan penggempur PKM berlindung. ${ }^{24} \mathrm{Di}$ samping itu, tugas utama Pasukan Cawangan Khas PDRM adalah bagi menghapuskan pergerakan bawah tanah komunis yang dikenali sebagai Min Yuen yang berperanan sebagai anggota bawah tanah yang bertanggungjawab bagi membekalkan pasukan penggempur dengan bekalan asas seperti makanan, bekalan perubatan, wang tunai, serta pakaian bagi membantu kelangsungan perjuangan bersenjata PKM di hutan untuk jangka masa yang panjang. ${ }^{25}$

Tugas menghapuskan pergerakan Min Yuen adalah amat mencabar kerana kebiasaannya anggota Min Yuen yang direkrut ini adalah mereka (individu) yang menjalani kehidupan biasa dalam masyarakat seperti petani, penjual ikan di pasar, orang kampung, pekedai runcit, penoreh getah serta sesiapapun yang dirasakan sesuai. ${ }^{26}$ Keadaan ini amatlah menyukarkan Pasukan Cawangan Khas PDRM bagi mengenalpasti ahli-ahli Min Yuen yang beroperasi di sesebuah tempat. Mengapakah Pasukan Cawangan Khas PDRM begitu obses dalam memusnahkan pergerakan Min Yuen? Organisasi bawah tanah Min Yuen dilihat secara dasarnya sebagai ancaman utama kepada kejayaan operasi ketenteraan yang dijalankan bagi menggempur pasukan komunis dalam hutan. Ini kerana ejen-ejen Min Yuen berperanan sebagai ejen perisikan bagi pihak PKM dalam mengenal pasti pergerakan pasukan keselamatan ketika operasi memburu komunis dilancarkan. ${ }^{27}$

Sebagai contoh, terdapat suatu kes seorang isteri kepada anggota Pasukan Polis Hutan sedang membeli ikan bilis di sebuah pasar di sesebuah daerah. Penjual ikan bilis itu adalah salah seorang daripada ejen Min Yuen telah bertanya kepada isteri tersebut mengapakah beliau membeli ikan bilis dalam kuantiti yang banyak. Lantas si isteri tersebut memberitahu pekedai tersebut bahawa suaminya akan terlibat dalam operasi di daerah tersebut pada keesokan harinya. Pekedai runcit tersebut lantas menyampaikan mesej yang diterimanya tadi kepada ejen Min Yuen yang lain lantas akan memberikan kelebihan kepada pasukan penggempur PKM bagi bersedia untuk menjangkakan bahawa pasukan keselamatan akan datang bagi memburu mereka di kawasan mereka berkubu. Ini akan memberikan kelebihan kepada pasukan penggempur PKM untuk menjalankan serang hendap terhadap konvoi pasukan keselamatan yang sedang bergerak kekawasan kubu mereka mahupun memberikan mereka kelebihan untuk beralih ke lokasi mereka berasa selamat dan ketika pasukan keselamatan tiba di kawasan operasi, pasukan penggempur komunis mungkin telah lama meninggalkan kawasan terbabit tanpa sebarang kecelakaan. ${ }^{28}$ Terdapat juga kes ejen Min Yuen dalam kalangan penoreh getah telah berjaya memberi 
isyarat kepada pasukan penggempur PKM tentang kedatangan pasukan keselamatan di sekitar kawasan operasi yang bakal dijalankan kerana secara kebiasaannya, lokasi kemasukan ke kawasan operasi bagi mencari dan memusnahkan gerila komunis dalam kawasan hutan-hutan simpan di Semenanjung Malaysia adalah berhampiran dengan kawasan ladang-ladang getah serta kelapa sawit. ${ }^{29}$ Ini adalah di antara faktor mengapa pasukan Cawangan Khas berusaha dengan keras bagi menghapuskan gerakan bawah tanah Min Yuen yang beroperasi di serata negara.

Selain mengesan kedudukan musuh dan memusnahkan pergerakan bawah tanah Min Yuen, Pasukan Cawangan Khas PDRM juga bertanggungjawab dalam mengesan kedudukan tempat simpanan bekalan makanan serta persenjataan pasukan penggempur PKM yang juga dikenali sebagai Food Dump dan Arms Dump. ${ }^{30}$ Food Dump adalah sebuah kawasan gerila komunis menanam dan menyimpan bekalan makanan ataupun peluru serta senjata dengan cara menanam di suatu lokasi yang dirasakan selamat serta tidak mudah untuk dijumpai oleh rondaan Pasukan Keselamatan. Kaedah ini dilakukan bertujuan bagi mengekalkan serta memastikan bahawa pasukan penggempur PKM sentiasa mempunyai bekalan makanan serta peluru yang tidak terhad. Pada masa yang sama, kaedah ini membolehkan pasukan penggempur PKM mempunyai pelan kontigensi sekiranya bekalan makanan mahupun peluru terputus akibat tekanan yang ditunjukkan oleh rondaan pasukan keselamatan yang begitu kerap memburu mereka dari semasa ke semasa. ${ }^{31}$

Terdapat beberapa taktik yang digunakan oleh komunis bagi menyimpan makanan serta peluru bagi mengekalkan keadaan makanan serta peluru supaya tidak rosak dalam tempoh jangka masa yang panjang apabila ditanam dalam tanah yang mana keadaan sekelilingnya yang lembap, panas serta basah akan mempercepatkan proses makanan serta peluru menjadi rosak. Kebanyakan daripada makanan serta peluru akan disimpan dalam bekas yang kalis udara serta air seperti tin biskut, tin minyak masak, bekas plastik, tong drum, serta lain-lain bekas yang dirasakan mampu menahan keadaan persekitaran dalam hutan yang ekstrim. ${ }^{32}$ Kebiasaannya, tong-tong serta bekas terbabit akan disalai dan disapukan dengan sejenis damar yang boleh didapati daripada pokok damar yang tumbuh meliar dalam hutan. Damar berfungsi sebagai pelindung semula jadi yang akan mengelakkan tin-tin yang digunakan bagi menyimpan bekalan makanan serta peluru yang ditanam daripada menjadi berkarat, kalis air, serta kedap udara. ${ }^{33}$ Dengan ini makanan serta peluru yang ditanam di kawasan yang telah ditetapkan mampu disimpan sehingga bertahun lamanya dengan kaedah penyimpanan yang betul. ${ }^{34}$

Pasukan Cawangan Khas PDRM mempunyai tugas yang sangat mencabar dalam mengenal pasti lokasi serta kedudukan food dump serta arms dump yang telah disorokkan oleh pasukan penggempur PKM kerana lokasi food dump disorokkan tidak diketahui oleh semua ahli komunis. Kebiasaanya, maklumat berkaitan lokasi food dump diketahui melalui proses soal siasat yang dijalankan terhadap anggota musuh yang menyerah diri kepada pihak berkuasa ataupun ditangkap oleh Surrendered Enemy Personnel (SEP). ${ }^{35}$ Tambahan pula, untuk mengesan lokasi food dump serta arms dump, anggota Medan Cawangan Khas perlu mempunyai kepakaran yang tersendiri serta mata yang terlatih bagi mengesan kedudukan sebenar food dump tersebut ditanam. Ini kerana, anggota komunis telah dilatih untuk menandakan kawasan mereka menyorokkan makanan terbabit dengan menggunakan simbol serta lakaran tanda yang tertentu menggunakan batu, daun, buluh, serta torehan di pokok hutan. ${ }^{36}$

Pengetahuan khas ini kebiasaannya dipelajari oleh anggota Pasukan Cawangan Khas PDRM melalui kursus perisikan tertentu yang dikelolakan oleh peringkat Pasukan yang turut mendapat kerjasama daripada bekas anggota komunis yang telah menyerah diri kepada pihak berkuasa sebelum ini. ${ }^{37}$ Pasukan Cawangan Khas PDRM sangat menitik beratkan usaha bagi memusnahkan bekalan makanan serta peluru pihak komunis yang ditanam di serata hutan di seluruh kawasan Semenanjung Malaysia. Ini kerana apabila 
sesebuah food dump serta arms dump berjaya dimusnahkan oleh pasukan keselamatan, ia sekali igus akan melumpuhkan pergerakan Unit-unit Penggempur PKM. Ini kerana secara dasarnya, manusia memerlukan makanan untuk hidup dan sekiranya pasukan komunis terputus bekalan makanan, ia akan melemahkan stamina serta moral anggota-anggota PKM bagi meneruskan perjuangan mereka dalam hutan. ${ }^{38}$ Tambahan pula, keadaan kehidupan dalam hutan yang ekstrim serta cuaca yang tidak menentu sudah pasti akan menyukarkan urusan seharian mereka. Pada 14 Mac, 25 April dan 28 April 1974, pasukan penggempur PKM yang beroperasi di kawasan hutan di Sungai Liang, Pahang telah dijumpai mati akibat kebuluran kesan daripada operasi rondaan pasukan keselamatan di kawasan terbabit yang menimbulkan tekanan kepada pasukan penggempur PKM tersebut yang terputus bekalan makanan. ${ }^{39}$ Pasukan Cawangan Khas PDRM juga akan membuat analisis terhadap barang makanan serta peluru yang dirampas bagi mengenal pasti kekuatan sebenar pasukan penggempur PKM di kawasan food dump dan arms dump tersebut ditemui. ${ }^{40}$

Ketika Darurat 1968-1989, Pasukan Cawangan Khas PDRM juga turut mempunyai tanggungjawab yang besar dalam menembusi sistem komunikasi bawah tanah PKM.41 Sistem Komunikasi amatlah penting dalam memastikan bahawa segala arahan daripada pihak Jawatankuasa Pusat PKM dapat dijalankan oleh pasukan penggempur PKM yang berada di serata negeri di Semenanjung Malaysia. PKM tidak menggunakan alat transmitter komunikasi ataupun battlefield radio ketika menyampaikan sesuatu arahan kepada pasukan penggempur PKM mereka kerana faktor-faktor keselamatan. Secara amnya, transmisi radio menggunakan gelombang yang dilancarkan daripada unit komunikasi wayarles mampu dipintas oleh pihak pasukan keselamatan yang turut dilengkapi dengan kemudahan radio Medan yang lebih canggih, sekali gus mampu menggugat keselamatan pasukan penggempur PKM apabila rancangan mereka mungkin boleh dikesan oleh pasukan keselamatan dengan hanya memintas transmisi radio perhubungan mereka. ${ }^{42}$

Tambahan pula, keadaan bentuk muka bumi Semenanjung Malaysia yang bergunung-ganang serta berhutan tebal menghadkan liputan kawasan bagi penggunaan gelombang radio wayarless. ${ }^{43}$ Sebagai langkah berjaga-jaga, pasukan penggempur PKM telah menggunakan sistem "pembawa utusan" ataupun dikenali sebagai "Jungle courier". ${ }^{44}$ Jungle courier adalah seorang individu yang dipilih oleh pihak PKM yang ditugaskan untuk menyampaikan mesej arahan perintah daripada Jawatankuasa Pusat PKM yang berpengkalan di selatan Thailand untuk masuk ke Semenanjung Malaysia. Jungle courier juga turut digunakan oleh pasukan penggempur PKM untuk berhubung dengan pasukan penggempur PKM yang berada di negeri-negeri lain di Semenanjung Malaysia. ${ }^{45}$ Jungle courier akan ditugaskan untuk membawa mesej penting kepada unit yang telah ditugaskan. Mesej tersebut ditulis di atas kertas yang kecil (rolling slip) dan disembunyikan di suatu tempat pengambilan yang dinamakan sebagai "Peti Surat Mati" ataupun lebih dikenali sebagai "Dead Letter Box (DLB)". 46

Lokasi-lokasi DLB ini hanya diketahui oleh jungle courier dan sistem pengesanan DLB ini adalah rumit seperti mana bagi mengesan lokasi food dump yang telah diterangkan sebelum ini. ${ }^{47}$ Tugas Pasukan Cawangan Khas PDRM adalah bagi mengenal pasti lokasi DLB yang telah dibina oleh anggota bawah tanah komunis. Ini kerana apabila DLB dapat dijumpai, Pasukan Cawangan Khas PDRM mampu menembusi sistem komunikasi rahsia PKM dengan memanipulasi maklumat arahan yang telah diberikan oleh pasukan penggempur PKM sebelum ini. Sebagai contoh, antara maklumat yang terkandung dalam DLB adalah lokasi serta masa pertemuan ejen-ejen komunis untuk mengambil bekalan makanan yang telah disiapkan oleh anggota Min Yuen mahupun lokasi mesyuarat di antara kader-kader PKM dalam sesebuah daerah. ${ }^{48}$ Dengan cara memanipulasi maklumat tersebut, Pasukan Cawangan Khas PDRM mampu mengenalpasti niat serta gerak kerja PKM sekali gus memudahkan pasukan keselamatan untuk membuat serang hendap di lokasi pertemuan ahli-ahli PKM yang telah ditetapkan sepertimana yang telah tercatat dalam 
DLB $^{49}$. Kaedah ini adalah salah satu cara bagaimana organisasi Min Yuen serta sistem komunikasi rahsia PKM dapat dihancurkan oleh Pasukan Cawangan Khas PDRM ketika Darurat 1968-1989. Hasilnya, pasukan keselamatan telah berjaya menghapuskan serta menangkap sejumlah anggota kumunis sekali gus melumpuhkan sistem komunikasi rahsia PKM secara berterusan.

\section{Taktik Perisikan Bagi Menghapuskan Ancaman Komunis}

Sememangnya kita telah mengetahui bahawa Pasukan Cawangan Khas PDRM telah memikul bebanan yang besar dalam menjadi sebuah organisasi bagi mengumpul data perisikan terhadap aktiviti musuh ketika Darurat 1968-1989, memandangkan pihak musuh kali ini lebih bersedia dan terlatih jika dibandingkan dengan Darurat 1948-1960. PKM telah memperbesarkan angkatan pasukan penggempur PKM serta organisasi Min Yuen ke serata pelusuk negara dalam usaha mereka mengembangkan ideologi komunis di negara kita. Ini dapat dibuktikan melalui satu arahan rahsia yang dikeluarkan oleh Jawatankuasa Pusat PKM yang merupakan pendahuluan kepada rayuan rasmi PKM dalam bulan Jun 1968 supaya melancarkan pemberontakan bersenjata yang berbunyi: "Semua Kader-Kader yang diburu oleh pihak musuh dan tidak boleh lagi bergerak dalam barisan terbuka hendaklah dengan penuh tekad bergerak bawah tanah, menubuhkan pertubuhan bawah tanah dan meneruskan perjuangan di bawah tanah" ${ }^{50}$

Pada masa yang sama, PKM juga telah mendapat bantuan secara langsung mahupun tidak langsung daripada parti-parti komunis di luar negara dari segi latihan ketenteraan mahupun alatan persenjataan ${ }^{51}$ membuatkan tugas pasukan keselamatan lebih mencabar dalam menumpaskan kegiatan musuh yang berleluasa pada tahun 1970-an. Dalam usaha membanteras ancaman bersenjata komunis, Pasukan Cawangan Khas PDRM telah menggunakan beberapa pendekatan yang ideal dalam menjalankan taktik perisikan bagi mengumpulkan maklumat tentang aktiviti musuh di lapangan (hutan).

Proses pengumpulan maklumat perisikan dilakukan secara meluas berdasarkan kepada prinsip perisikan Manusia (Human Intelligence). Terdapat beberapa jenis taktik dalam pemerolehan data risikan di lapangan. Taktik yang paling popular dilaksanakan oleh Pasukan Cawangan Khas PDRM adalah dengan kaedah menghantar anggota lapangan ke kawasan yang didiami oleh musuh secara langsung. ${ }^{52}$ Kebiasaanya anggota Pasukan Cawangan Khas PDRM akan berpakaian seperti orang kampung ataupun menyamar sebagai pencari rotan bagi mengelakkan penyamaran mereka terbongkar. 53 Dalam sesetengah kes, pencari rotan mahupun orang asli menjadi kebiasaan bagi mereka bertembung dengan ejen mahupun komunis yang berkeliaran di sekeliling kawasan hutan. Di kawasan kampung-kampung yang terpencil, adalah menjadi suatu kebiasaan apabila kebanyakan daripada penduduk kampung yang mencari nafkah sebagai pemungut hasil hutan dan penyamaran sebegini akan mengurangkan syak wasangka anggota komunis sekiranya anggota perisikan Pasukan Cawangan Khas PDRM bertembung dengan komunis di tengah hutan belantara. ${ }^{54}$

Maklumat perisikan yang kebiasaannya ditumpukan oleh anggota Pasukan Cawangan Khas PDRM adalah seperti lokasi kem-kem musuh berada, kekuatan ataupun bilangan anggota musuh yang berada di sesebuah kubu pertahanan, kekuatan persenjataan anggota komunis, bentuk pakaian seragam musuh, serta lokasi jerangkap samar mahupun sentri yang berada disekeliling perimeter kawasan kubu musuh. ${ }^{55}$ Aktiviti pengumpulan perisikan yang dijalankan oleh anggota lapangan ini kebiasaannya mengambil masa satu hari dan mereka tidak dibekalkan dengan apa-apa bentuk senjata api tetapi kebiasaannya mereka dibekalkan dengan sebilah pisau mahupun parang dan sedikit bekalan makanan. ${ }^{56}$ Darjah risiko yang mungkin dihadapi oleh anggota perisikan Pasukan Cawangan Khas PDRM di lapangan amatlah tinggi terutamanya sekiranya mereka ditangkap oleh pasukan 
komunis, kebarangkalian untuk mereka hidup adalah tipis sekali. Akan tetapi sekiranya mereka berjaya dalam sesebuah misi, maka data perisikan yang telah dikumpul daripada lapangan amatlah berguna kepada pasukan keselamatan kerana darjah ketepatan risikan tersebut kebiasaannya adalah tinggi serta tepat yang memungkinkan kejayaan sesebuah operasi serang hendap musuh yang bakal dijalankan kemudian.

Selain daripada menghantar ejen ke lapangan untuk mengutip data perisikan secara langsung, pasukan Pasukan Cawangan Khas PDRM juga turut menggunakan taktik memanipulasikan anggota-anggota musuh yang telah menyerah diri kepada pasukan keselamatan sebelum ini yang turut dikenali sebagai SEP dan CEP. ${ }^{57}$ Anggota SEP ini adalah bekas anggota komunis yang telah menyerah diri mahupun meninggalkan perjuangan mereka. Setelah disoal siasat oleh pasukan keselamatan, kebiasaannya anggota SEP akan bekerjasama dengan pihak pasukan keselamatan mahupun Pasukan Cawangan Khas PDRM bagi mendedahkan maklumat-maklumat berkaitan dengan pergerakan kumpulan bersenjata yang pernah mereka sertai sebelum ini. ${ }^{58}$

Seringkali SEP akan mendedahkan lokasi markas pasukan yang mereka pernah sertai berada. Maklumat-maklumat seperti nama kader-kader mahupun komander rejimen ataupun pasukan penggempur PKM, kekuatan pasukan, lokasi food dump, persenjataan, serta lain lain lagi maklumat yang berguna kepada perisikan Pasukan Cawangan Khas PDRM akan dimanipulasikan dengan sebaik mungkin bagi memberikan kelebihan kepada pasukan keselamatan untuk memburu serta memerangkap musuh melalui operasi Cari dan Musnah yang bakal dijalankan kemudian. ${ }^{59}$ Tidak dapat dinafikan bahawa peranan yang ditunjukkan oleh anggota SEP dalam memberikan maklumat perisikan terhadap musuh, amat membantu pasukan keselamatan terutamanya Pasukan Cawangan Khas PDRM dalam memusnahkan komunis dengan mendapat kejayaan yang cemerlang.

Selain daripada SEP, terdapat satu lagi sumber perisikan yang digunakan oleh Pasukan Cawangan Khas PDRM sebagai taktik dalam mendapatkan data perisikan iaitu dengan menggunakan Agen Gred Khas ataupun dikenali sebagai Special Grade Agent (SGA). SGA merupakan anggota musuh yang telah menyerah diri ataupun ditangkap oleh pasukan keselamatan akan tetapi, masih lagi mempunyai hubungan yang baik dengan unit lama yang mereka pernah sertai. Dalam erti kata lain, SGA masih lagi dipercayai oleh rakan dalam pasukan mereka kerana mereka tidak mengetahui bahawa rakan mereka pernah ditangkap oleh pasukan keselamatan sebelum ini. SGA akan menyusup masuk semula ke dalam unit lama mereka dan akan menjalankan tugas mereka seperti biasa. Akan tetapi tanpa diketahui oleh anggota komunis yang lain, SGA telah menjadi ejen perisikan bagi pihak kerajaan ${ }^{60}$. SGA juga tidak semestinya anggota musuh yang menyerah diri, akan tetapi mereka juga merupakan individu biasa yang tinggal dalam sesebuah tempat, akan tetapi mempunyai hubungan yang baik dengan anggota musuh. SGA juga berperanan sebagai mata dan telinga bagi pasukan keselamatan dan dalam sesetengah kes, mereka akan dibayar elaun imbuhan sekiranya berjaya memberikan maklumat perisikan terhadap musuh dengan tepat ataupun maklumat perisikan yang telah diberikan oleh mereka membuahkan hasil dengan tertangkapnya ataupun terbunuhnya pemimpin utama dalam Rejimen mahupun pasukan penggempur PKM.61

Tugas SGA juga mempunyai darjah risiko bahaya yang tinggi. Sekiranya mereka ditangkap oleh komunis, mereka akan diseksa hingga mati oleh anggota skuad penggempur PKM kerana terdapat kes apabila penyamaran SGA terbongkar apabila mereka membelanjakan wang hasil daripada elaun yang telah diberikan oleh pihak pasukan keselamatan secara berlebihan sehingga menimbulkan syak wasangka pasukan komunis. Pihak komunis melihat SGA tersebut berbelanja di luar daripada kemampuan diri mereka sebagai seorang petani lantas menyebabkan pihak komunis berasa curiga bahawa SGA tersebut merupakan tali barut pasukan keselamatan yang dibayar. ${ }^{62}$ Terdapat lagi beberapa taktik yang digunakan selain daripada tiga jenis taktik yang disebutkan di atas iaitu Agen 
lapangan, SEP, dan SGA. Tetapi atas faktor kerahsiaan, maka taktik tersebut tidak diumumkan kepada pihak awam. Ketiga-tiga jenis taktik yang digunakan oleh Pasukan Cawangan Khas PDRM ini telah memberikan kejayaan yang besar dalam operasi mereka menghapuskan ancaman komunis pada tahun 1968 hingga 1989.

\section{Keberkesanan Pasukan Cawangan Khas PDRM Menghapuskan Komunis}

Cawangan Khas boleh diklasifikasikan sebagai sebuah badan perisikan yang sangat efektif, efisien serta terbukti kebekesanannya dalam menjalankan peranannya menghapuskan ancaman bersenjata yang dilancarkan oleh PKM pada Darurat 1968-1989. Pasukan Cawangan Khas PDRM dilihat sebagai sebuah pasukan yang mendatangkan impak yang besar terhadap operasi pembanterasan komunis sama ada dalam bandar mahupun di luar bandar. Walaupun usia penubuhan Pasukan Cawangan Khas PDRM boleh dianggap sebagai masih muda jika dibandingkan dengan agensi perisikan utama di dunia seperti Agensi Perisikan Pusat Amerika Syarikat (CIA) dan Perkhidmatan Keselamatan Dalam Negara Rusia (KGB) yang berpengalaman dalam menjalankan program perisikan medan, akan tetapi Pasukan Cawangan Khas PDRM telah mempamerkan hasil yang memberikan impak yang besar terhadap keselamatan negara. Buktinya dapat dilihat melalui operasi serbuan yang dijalankan di kawasan bandar yang terdapat penyokong-penyokong PKM mahupun ahli gerakan bawah tanah komunis berlindung di kawasan bandar utama di Semenanjung Malaysia seperti di Ipoh ${ }^{63}$ dan Kuala Lumpur ${ }^{64}$ sekitar tahun 1970-an.

Pada masa yang sama, tugas Pasukan Cawangan Khas PDRM dalam menembusi sistem komunikasi rahsia gerakan bawah tanah Min Yuen turut membuahkan hasil yang besar dalam usaha memastikan pengaruh PKM dihapuskan secara berterusan. Ini dapat dilihat melalui bilangan anggota komunis yang dapat ditangkap, dibunuh, mahupun menyerah diri sepanjang tempoh Darurat 1968-1989 yang telah bertambah dari semasa ke semasa. 65 Dalam pada itu peranan Pasukan Cawangan Khas PDRM dalam mendapatkan maklumat daripada anggota-anggota SEP yang ditangkap mahupun menyerah diri adalah di antara taktik utama menghasilkan kemenangan kepada pihak pasukan keselamatan melalui operasi ketenteraan menghapuskan pasukan penggempur PKM di seluruh Semenanjung Malaysia. ${ }^{66}$

Maklumat yang diekstrak daripada SEP mahupun dokumen-dokumen yang dijumpai pada mayat komunis yang berjaya dibunuh menjadi suatu informasi yang berharga terhadap sistem perisikan yang telah dijalankan oleh Pasukan Cawangan Khas PDRM. Usaha mereka mentafsir dokumen-dokumen komunis yang kebanyakannya ditulis dalam Bahasa Cina telah dibantu oleh sekumpulan kecil anggota-anggota Pasukan Cawangan Khas PDRM berbangsa Cina yang berdedikasi serta mempunyai semangat patriotik yang tinggi dalam mempertahankan negara daripada ancaman musuh turut membuahkan hasil.67 Kesanya, sebahagian besar daripada maklumat berkaitan dengan aktiviti, serta niat pasukan musuh dalam membuat kekacauan dalam negara dapat ditafsirkan oleh pasukan, lantas memberikan kelebihan kepada Pasukan Cawangan Khas PDRM bagi menghalang PKM daripada menjalankan rancangan serangan mahupun sabotaj terhadap negara kita pada ketika itu. Walau bagaimanapun, Pasukan Cawangan Khas PDRM terpaksa menghadapi pelbagai risiko serta cabaran dalam menjalankan tugas serta tanggungjawab bagi mempertahankan tanah air daripada cengkaman musuh.

Dekad 1970-an menunjukkan Pasukan Cawangan Khas PDRM terpaksa membayar perjuangan mereka dengan harga yang mahal apabila terdapat ramai daripada anggotaanggota lapangan daripada pasukan mereka khususnya anggota yang berbangsa Cina telah dibunuh oleh pasukan penggempur PKM di beberapa buah negeri seperti di Kedah, Perak, Selangor dan Kuala Lumpur. ${ }^{68}$ PKM merasakan bahawa Pasukan Cawangan Khas PDRM merupakan punca kepada segala masalah dalam menghalang aktiviti pemberontakan 
bersenjata yang telah dilancarkan oleh mereka. Mereka menjadikan anggota Pasukan Cawangan Khas PDRM khususnya yang berbangsa Cina sebagai sasaran utama pembunuhan kerana PKM menganggap bahawa mereka adalah golongan pengkhianat yang sanggup berpaling tadah dengan membunuh bangsa mereka sendiri. ${ }^{69}$ Tambahan pula, anggota Pasukan Cawangan Khas PDRM berbangsa Cina amat mudah menyamar sebagai anggota komunis disebabkan kebolehan mereka untuk berkomunikasi dalam bahasa Cina dengan fasih. Justeru itu, taktik ini mudahkan mereka untuk melakukan taktik penyamaran dengan menyamar sebagai anggota komunis dilengkapi dengan uniform untuk menembusi ke dalam kumpulan pasukan penggempur PKM tanpa menimbulkan sebarang syak wasangka. ${ }^{70}$

Tahun demi tahun berlalu, perjuangan bersenjata PKM mula menampakkan bibitbibit kelemahan apabila pada akhir tahun 1970-an berlaku perpecahan dalam organisasi PKM yang menyebabkan PKM telah berpecah menjadi 3 buah organisasi. ${ }^{71}$ Keadaan PKM bertambah buruk apabila bermula tahun 1980-an, hasil kebijaksanaan pemimpin negara melalui rundingan meja bulat telah berhasil menyebabkan Parti Komunis China bersetuju untuk menghentikan segala bantuan ketenteraan kepada PKM tetapi mengambil langkah sekadar memberikan sokongan moral kepada perjuangan PKM.72 Nasib seperti tidak menyebelahi PKM pada tahun 1980-an apabila rakan seperjuangan mereka iaitu Parti Komunis Thailand (PKT) telah mengambil langkah untuk menamatkan perjuangan bersenjata mereka secara rasmi dengan meletakkan senjata kepada kerajaan Thailand.73 Senario politik dunia turut berubah apabila di akhir tahun 1980-an, kebanyakan daripada negara-negara di Blok Eropah Timur sudah mula berpecah daripada pemerintahan Kesatuan Sosialis Republik Soviet Union.

Kebanyakan negara dalam Blok Komunis termasuk negara China dan Vietnam telah mengamalkan Dasar Polisi Keterbukaan dalam hubungan serantau serta ekonomi telah memperlihatkan ideologi Komunisme serta Sosialisme semakin tidak relevan dengan arus perubahan zaman.74 Kebanyakan -negara Komunis di dunia mempunyai pertumbuhan negara yang mundur serta lembab jika dibandingkan dengan negara-negara dalam Blok Kapitalis seperti Amerika Syarikat, United Kingdom, Perancis, dan Jerman Barat yang lebih maju berkembang selaras dengan arus peredaran semasa. Setelah hampir 40 tahun mengangkat senjata, akhirnya PKM telah bersetuju untuk menamatkan perjuangan bersenjata mereka yang dianggap sebagai sia-sia melalui termetrainya Perjanjian Damai Hat Yai yang berlangsung pada tahun $1989 .{ }^{75}$

\section{Kesimpulan}

Pasukan Cawangan Khas PDRM dilihat sebagai pasukan yang telah memberikan kelebihan yang besar kepada pasukan keselamatan dalam menghapuskan ancaman bersenjata PKM ketika Darurat 1968-1989. Pasukan Cawangan Khas PDRM telah membuktikan peranannya sebagai sebuah organisasi yang mengumpulkan data perisikan bagi faktor kekalahan PKM. Pasukan Cawangan Khas PDRM telah mengambil pengalaman mereka ketika Darurat 19481960 dalam melawan komunis dengan sebaik mungkin apabila mereka mengambil langkah proaktif dengan membangunkan organisasi pasukan untuk menjadi lebih efisien serta sistematik. Ini dapat dibuktikan melalui penubuhan Divisyen E1 hingga E8 yang beroperasi mengikut kepakaran serta tugas setiap jabatan dalam pasukan dengan lebih teratur serta mengikut kepakaran anggota masing-masing.

Darurat 1968-1989 juga telah memberikan pengalaman yang bermakna kepada Pasukan Cawangan Khas PDRM apabila keupayaan serta taktik pasukan dalam menangani ancaman bersenjata PKM menjadi lebih mencabar. Pada ketika itu, PKM dilihat lebih bersedia dalam melancarkan serangan terhadap kerajaan apabila mereka telah mempertingkatkan kesiap siagaan unit-unit serta pasukan penggempur PKM yang turut 
mendapat bantuan persenjataan serta latihan daripada Parti Komunis China serta Parti Komunis Vietnam yang mempunyai pengalaman besar dalam menjalankan aktiviti perang gerila terutamanya apabila pasukan tentera Vietnam telah berjaya mengalahkan tentera Amerika Syarikat ketika Perang Vietnam 1963-1974.

Kekuatan serta strategi peperangan gerila yang dilancarkan oleh PKM telah dilihat membuahkan hasil dalam menguji tahap kecekapan serta kesediaan Pasukan Cawangan Khas PDRM ketika tahun 1970-an. Pasukan Cawangan Khas PDRM telah berusaha untuk menggunakan seberapa banyak taktik bagi menghancurkan sistem komunikasi organisasi PKM dengan cara menjalankan akitviti perisikan medan melalui penghantaran ejen lapangan. Pada masa yang sama, anggota musuh yang telah menyerah diri (SEP) mahupun ditangkap oleh pasukan keselamatan telah dimanipulasi sebaik mungkin oleh Pasukan Cawangan Khas PDRM bagi membantu pasukan dalam menghapuskan PKM secara langsung. Kaedah ini turut mendorong kejayaan Pasukan Cawangan Khas PDRM bukan sahaja dengan menembusi sistem komunikasi PKM malahan dalam sesetengah kes, ianya turut membuahkan hasil yang lebih besar apabila kaedah tersebut mampu membantu pasukan keselamatan dalam menghapuskan pemimpin kanan PKM di peringkat Jawatankuasa Daerah atau Jawatankuasa Negeri.

Dalam usaha Pasukan Cawangan Khas PDRM membanteras kegiatan bersenjata PKM pada tahun 1970-an, mereka turut mengalami tekanan yang berterusan daripada pihak komunis. Ini dapat dilihat apabila pada sekitar tahun 1970-an, pihak komunis melalui pasukan penggempur PKM telah berjaya melancarkan serangan terhadap beberapa orang anggota Pasukan Cawangan Khas PDRM di seluruh Semenanjung Malaysia. Serangan tersebut dilihat sebagai salah satu usaha yang dilakukan oleh PKM untuk melemahkan kegiatan pengumpulan perisikan yang dijalankan oleh Pasukan Cawangan Khas PDRM. Serangan tersebut juga menjadi suatu bentuk pembalasan yang bersifat dendam terhadap kematian rakan-rakan persejuangan dalam pasukan mereka yang mungkin terbunuh akibat pertempuran dengan pihak pasukan keselamatan hasil daripada sumber perisikan anggota Pasukan Cawangan Khas PDRM yang berdedikasi dalam menjalankan tugas mereka tanpa mengira bahaya yang menyebabkan mereka kehilangan nyawa.

Secara amnya, Pasukan Cawangan Khas PDRM merupakan salah sebuah daripada pasukan yang memberikan kejayaan yang besar khususnya kepada kejayaan negara dalam menangani ancaman bersenjata PKM pada Darurat 1968-1989. Pada hari ini, Cawangan Khas masih lagi beroperasi dalam pasukan PDRM dan kecekapan serta kualiti mereka masih lagi pada tahap yang tinggi. Walaupun ancaman bersenjata komunis telah tamat hampir 3 dekad yang lalu, akan tetapi Pasukan Cawangan Khas PDRM pada masa kini menghadapi ancaman keselamatan yang lebih besar daripada apa yang pernah mereka lalui sebelum ini terutamanya apabila mereka terpaksa menghadapi ancaman yang bersifat global seperti ancaman keganasan terorisme, serta pergerakan persatuan yang bersifat extremisme yang dilihat mampu menghancurkan kestabilan politik serta sosial di sesebuah negara seperti ancaman Pertubuhan Negara-Negara Islam Iraq dan Syria (IS) yang semakin menular sehingga ke Asia Tenggara. Ancaman seperti ini telah memberikan Pasukan Cawangan Khas PDRM tanggungjawab yang lebih besar dalam mempertahankan keselamatan dalam negeri serta negara dengan lebih aktif.

\section{Nota}

1 Lihat C.C. Too, "International Seminar on Communism in Asia 1966", hlm. 5. Arkib Negara Malaysia. ANM 2006/0007931/W/A/04/A/04/E/3.

2 Menurut Leon Comber, Pasukan Cawangan Khas Polis Persekutuan Malaya (SB) telah ditubuhkan secara rasmi pada tahun 1948. Akan tetapi SB adalah sebuah organisasi yang 
diwujudkan hasil daripada legasi yang ditinggalkan oleh Perkhidmatan Keselamatan Malaya ataupun dikenali sebagai Malaya Security Service yang telah ditubuhkan sebelum berlakunya Perang Dunia Kedua. Lihat Leon Comber, Malaya's Secret Police 1945-1960: The Role of the Special Branch in the Malayan Emergency, Singapore: Institute of Southeast Asian Studies, 2008, hlm. 26-27. 3 Ibid., hlm. 289.

4 R.W. Komer, "The Malayan Emergency in Retrospect: Organization of a Successful Counterinsurgency Efforts", Report for the Advanced Research Projects Agency, RAND Corporation, Santa Monica, California, USA, Febuari 1972, hlm. 41-45.

5 Anthony Short, In Pursuits of Mountain Rats: The Communist Insurrection in Malaya, Singapore: Cultured Lotus, 2000, hlm. 80.

6 Leong Chee Who, Scorpio the Communist Eraser, USA: Rocky Mountain Press, 1996, hlm. 357-358.

7 Mohd Reduan Haji Asli, Pemberontakan Bersenjata Komunis di Malaysia, Kuala Lumpur: Dewan Bahasa dan Pustaka, 1993, hlm. 36-37.

8 Perdana Menteri Tanah Melayu pertama, Tunku Abdul Rahman Putra al-Haj secara rasmi telah mengisytiharkan berakhirnya darurat pada 31 Julai 1960. Lihat John Nagl, Learning to Eat Soup with a Knife: Counterinsurgency Lessons from Malaya and Vietnam, USA: University of Chicago Press, 2005, hlm. 103.

$9 \quad$ PKM telah mengundurkan keseluruhan Unit-Unit Penggempur Bersenjata mereka ke kawasan hutan di selatan Thailand meliputi kawasan Songkhla, Narathiwat, Yala dan Patani sejurus berakhirnya Darurat pada tahun 1960 sebagai langkah bagi membina semula kekuatan dalaman PKM. Lihat Ho Hui Ling, Pergerakan Bersenjata Parti Komunis Malaya 1968-1989: Kebangkitan Semula dan Penumpasannya, Kuala Lumpur: Penerbit Universiti Malaya, 2015, hlm. 44.

10 Unit Divisyen E adalah kod rasmi jabatan yang berada di bawah Pasukan Cawangan Khas Polis.

11 Deputy Commissioner Police (DCP) ataupun Timbalan Pesuruhjaya Polis adalah pangkat anggota dalam Kumpulan Pegawai Kanan Polis yang setaraf dengan Mejar Jeneral dalam perkhidmatan Tentera Darat dan Udara. Lihat Kerjaya dalam Pasukan Polis Diraja Malaysia, Cawangan Perhubungan Awam, Ibu Pejabat Polis Diraja Malaysia, Bukit Aman, Kuala Lumpur, 1975, hlm. 14.

12 Senior Assistant Commisioner of Police (SAC) ataupun Penolong Pesuruhjaya Kanan Polis adalah pangkat anggota dalam Kumpulan Pegawai Kanan Polis yang setaraf dengan pangkat Brigadier Jeneral dalam perkhidmatan Tentera Darat dan Udara. Lihat J.J. Raj, The Struggle for Malaysian Independence, Petaling Jaya: MPH Group Publishing Sdn. Bhd, 2007, hlm. 267-269.

13 Assistant Commisioner of Police (ACP) ataupun Penolong Pesuruhjaya Polis adalah pangkat anggota dalam Kumpulan Pegawai Kanan Polis yang setaraf dengan pangkat Kolonel dalam perkhidmatan Tentera Darat dan Udara. Lihat ibid., hlm. 267-269.

14 Nota peribadi SAC Datuk Dr. Leong Chee Woh, Bekas Timbalan Pengarah Cawangan Khas Polis Diraja Malaysia, Bukit Aman (1981-1984).

15 Sharom Hashim, Tentera Darat Menentang Insurgensi Komunis 1968-1989, Kuala Lumpur: Markas Tentera Darat, 2001, hlm. 6.

16 Leong Chee Who, Scorpio on the Dragon Demise: The Second Malayan Communist Insurgency Emergency 1970-1990, USA: Rocky Mountain Press, 2012, hlm. 14.

17 Arkib Negara Malaysia, The Communist threat to the Federation of Malaya 1959, ANM 2006/0007819, 2006, hlm. 19-30.

18 Sharom Hashim, Tentera Darat Menentang Insurgensi Komunis, hlm. 15.

18 A.V. Navaratnam, The Spear and The Kerambit: The Exploits of VAT 69, Malaysia's Elite Fighting Force 1968-1969, Kuala Lumpur: Utusan Publication and Distributor Sdn. Bhd, 2001, hlm. 5-6.

19 Ibid., hlm. 6.

20 Lihat "Munchulnya Semula Anchaman Kominis Bersenjata di Malaysia Barat", Kertas Putih Rasmi Kementerian Dalam Negeri, Oktober 1971, hlm. 7.

21 Ibid., hlm.3.

22 Mohd Reduan Haji Asli, Pemberontakan Bersenjata Komunis, hlm. 116.

23 Lihat Ramlah Adam, Pahlawan Tegar Merdeka, Kuala Lumpur: Dewan Bahasa dan Pustaka, 2014, hlm. 37.

24 Temu bual bersama Bekas Penolong Penguasa Polis, ASP Meor Roslan Dato' Meor Jaafar pada 16 November 2015. Beliau merupakan bekas anggota lapangan pasukan Cawangan Khas yang 
pernah berkhidmat ketika Darurat 1981-1984. Beliau kini berkhidmat sebagai pensyarah di Pusat Pengajian Strategik Pertahanan dan Keselamatan, Universiti Pertahanan Nasional Malaysia (UPNM), Kuala Lumpur.

Ismail Saad, 'Pemberontakan PKM: Mengapa Gagal?', dalam Khoo Khay Kim dan Adnan Haji Nawang (ed.), Darurat 1948-1960, Kuala Lumpur: Muzium Angkatan Tentera, 1984, hlm. 73. petani, serta orang awam sebagai salah satu kaedah bagi membentuk Barisan Bersatu Komunis bagi menentang kerajaan melalui pergerakan revolusi. Ini menyebabkan ramai golongan masyarakat terpengaruh dengan dakyah serta ideologi komunis yang menyebabkan mereka secara tidak langsung menganggotai organisasi Min Yuen dengan membantu PKM dalam memberikan maklumat persisikan terhadap Pasukan keselamatan. Lihat Arkib Negara Malaysia, “Operational Intelligence", ANM 1957/0537807 Ibid.

Ketika tahun 1970-an, Malaysia mengalami pertumbuhan ekonomi yang pesat terutamanya daripada sektor pertanian apabila Perdana Menteri ketika itu, Tun Abdul Razak telah melancarkan Dasar Ekonomi Baru bagi mebangunkan pertumbuhan Keluaran Dalam Negara Kasar (KDNK) negara. Salah satu kaedahnya adalah dengan meningkatkan pengeluaran hasil pertanian negara melalui penanaman tanaman komoditi negara seperti kelapa sawit dan getah. Sehubungan itu, banyak kawasan hutan telah ditebang bagi menjalankan projek tanaman komoditi secara besar yang diselaraskan oleh Lembaga Pembangunan Tanah Persekutuan (FELDA). Hasilnya dapat dilihat apabila pinggir hutan telah bertukar menjadi ladang kelapa sawit serta getah. Lihat Tun Abdul Ghafar Baba, 'Tun Razak Menyentuh Nadi Masyarakat Desa', dalam Shajaratuddur Sheikh Abdul Halim (ed.), Tun Abdul Razak Dalam Kenangan, Kuala Lumpur: Utusan Publication Sdn. Bhd., 2006, hlm. 184-185.

30 Food Dump kebiasaannya ditanam dalam kawasan operasi PKM. Lokasi yang dipilih adalah strategik dan sukar untuk dikesan dengan menggunakan pandangan mata kasar. Hanya segelintir ketua ataupun kader-kader komunis yang mengetahui lokasi sebenar food dump. Berdasarkan sumber perisikan, tebing bukit adalah lokasi yang paling sesuai digunakan bagi menempatkan food dump kerana lokasi tersebut tidak menakung air serta memudahkan proses pengambilan semula makanan oleh pasukan penggempur PKM. Sementara itu, Arms Dump adalah bekas yang berisi peluru dan bahan letupan yang disorok dalam tanah bagi memastikan pasukan penggempur PKM mempunyai bekalan peluru serta letupan yang tidak terhad untuk digunakan dari masa ke semasa. Lihat A.V. Navaratnam, The Spear and The Kerambit, hlm. 31. Ibid.

Sharom Hashim, Tentera Darat Menentang Insurgensi Komunis, hlm. 27.

A.V. Navaratnam, The Spear and The Kerambit, hlm. 29.

Lihat "Munchulnya Semula Anchaman Kominis", hlm. 22.

Ibid.

A.V. Navaratnam, The Spear and The Kerambit, hlm. 78, 85- 89.

Temu bual bersama ASP Meor Roslan Dato' Meor Jaafar, 16 November 2015.

38 Temu bual bersama Prof. Madya Dr. Kumar Ramakrishna, 16 Mac 2015, Rajaratnam School of International Studies, Universiti Teknologi Nanyang, Singapura. Dr. Kumar Ramakrishna merupakan pakar dalam bidang strategik pertahanan dan keselamatan, pengkhususan dalam bidang insurgensi dan darurat Tanah Melayu. Beliau juga merupakan Ketua Pusat Kajian Keselamatan Negara Singapura, Universiti Teknologi Nanyang, Singapura.

39 Lihat "Subversive Activities: How They Are Disrupted", Department of Information, Ministry of Information, 1976, hlm. 21. BK036(E).

40 Temu bual bersama SAC Datuk Dr. Leong Chee Woh, Bekas Timbalan Pengarah Cawangan Khas Bukit Aman (1981-1984), 24 Mei 2015. Datuk Dr. Leong Chee Woh merupakan bekas anggota lapangan (field operative) Pasukan Cawangan Khas PDRM dan pernah terlibat dalam beberapa operasi khas menghapuskan pemimpin kanan PKM ketika Darurat 1948-1960 dan Darurat 19681989. Beliau menganggotai Cawangan Khas PDRM sejak tahun 1953.

$41 \quad$ Arkib Negara Malaysia, “Operational Intelligence”, 1957/0537807. 

Menurut Leong Chee Woh, Dead Letter Box (DLB) adalah sebuah lokasi rahsia yang telah ditentukan oleh unit-unit bawah tanah PKM untuk mengambil mahupun meninggalkan surat arahan rahsia (rolled slips) yang digunakan sebagai sistem untuk organisasi PKM berkomunikasi di antara sebuah unit penggempur kepada unit bersenjata PKM yang lain dalam sesebuah kawasan. Kebiasaannya rolled slip adalah kertas yang dilipat dalam bentuk gulungan kecil sebesar saiz sebatang pensil bagi memudahkannya disorok agar tidak mudah dikesan oleh pasukan keselamatan sekiranya penghantar surat terbabit (Jungle Courier) bertembung mahupun ditangkap oleh pasukan keselamatan. Lihat ibid, hlm. 7.

48 Temu bual bersama SAC Datuk Dr. Leong Chee Woh, Bekas Timbalan Pengarah Cawangan Khas Bukit Aman (1981-1984), 24 Mei 2015.

49 Temu bual bersama ASP Meor Roslan Dato' Meor Jaafar, 16 November 2015.

50 Lihat "Munchulnya Semula Anchaman Kominis", hlm. 3.

51 Ketika Darurat 1968-1989, PKM telah mendapat bantuan secara langsung daripada Parti Komunis Cina dari segi logistik mahupun ketenteraan. Ini dapat dibuktikan apabila sejumlah peralatan ketenteraan seperti risalah ideologi Komunis dan senjata yang dirampas oleh pasukan keselamatan dihasilkan dari Republik Rakyat China. Lihat Zakaria Haji Ahmad dan Zakaria Hamid, "Violence at the Periphery: A Survey of Armed Communism in Malaysia", Kertas Kerja Dibentangkan Dalam Konferens Pegerakan Bersenjata Komunis di Asia Tenggara, Singapura, 1719 November 1982, hlm. 17.

52 Leon Comber, Malaya's Secret Police 1945-1960, hlm. 79.

53 Temu bual bersama SAC Datuk Dr. Leong Chee Woh, Bekas Timbalan Pengarah Cawangan Khas Bukit Aman (1981-1984), 24 Mei 2015.

54 Temu bual bersama bekas Prebet Mohamad Desa Othman, 22 Julai 2015, Kampung Jalong, Sungai Siput Utara, Perak. Beliau merupakan bekas anggota Pasukan Khas Perisikan Tempur (PKPT) Tentera Darat Malaysia yang berperanan dalam menjejak serta mendapatkan data perisikan lapangan terhadap anggota musuh. Pasukan Khas Perisikan Tempur bekerjasama rapat dengan Pasukan Cawangan Khas Polis dalam meningkatkan kerjasama perisikan dua hala antara PDRM dan Sel Perisikan Tentera Darat. Beliau adalah salah seorang anggota lapangan yang pernah menghadiri Kursus Asas Perisikan yang turut dikendalikan oleh Pasukan Cawangan Khas PDRM.

55 Lihat "Manual Kursus Asas Perisikan Tempur", Arkib Cawangan Markas Perisikan Pasukan Tentera Darat, Rujukan Terhad.

56 Temu bual bersama bekas Prebet Mohamad Desa Othman, 22 Julai 2015.

57 Anggota musuh yang menyerah diri ataupun dikenali sebagai Surrender Enemy Personnel (SEP) adalah anggota musuh yang menyerah diri kepada pasukan keselamatan. Kebiasaannya mereka adalah anggota komunis yang telah hilang kepercayaan kepada perjuangan PKM ataupun telah kehilangan moral untuk meneruskan perjuangan akibat tekanan psikologi yang telah dihasilkan oleh pasukan keselamatan melalui perang psikologi, ataupun keadaan sekeliling yang melemahkan stamina serta semangat perjuangan seperti kelaparan, serta tekanan perasaan apabila terus diburu oleh pihak berkuasa. Lihat C.C. Too, "Psychological Warfare and Some Aspects of the Psychology of the People in Southeast Asia in Areas Where Communist Insurrection is Likely to Arise", Impromptu Speech to the Staff of the Faculty at United States Amy Command and General Staff College, Fort Leavenworth, Kansas, USA, 15 Oktober 1962, hlm. 11-13. Arkib Negara Malaysia: 2008/0000241. 
Leong Chee Who, Scorpio the Communist Eraser, hlm. 158-159.

Pada tahun 1976, Pasukan Cawangan Khas PDRM berjaya menghapuskan sistem hab komunikasi utama bawah tanah PKM di negeri Perak hasil daripada serbuan Pasukan Cawangan Khas PDRM di Fairpark, Ipoh, Perak. Lihat Mohd Azzam Hanif Ghows, Reminiscences of Insurrection: Malaysia's Battle against Terrorism 1960-1990, Kuala Lumpur: Wangsa Zam, 2014, hlm. 187.

Sepanjang tahun 1969-1989, pasukan keselamatan telah berjaya membunuh seramai 212 anggota musuh, menawan 150 orang, serta sejumlah 117 orang anggota komunis menyerah diri kepada pihak keselamatan. Statistik Majlis Keselamatan Negara (MKN) ini menunjukkan keberkesanan peranan Pasukan Cawangan Khas PDRM dalam menangani ancaman bersenjata komunis di Semenanjung Malaysia. Lihat Sharom Hashim, Tentera Darat Menentang Insurgensi Komunis, hlm. 146.

66 Lihat "Subversive Activities: How They Are Disrupted", hlm. 5.

67 Salah satu usaha Pasukan Cawangan Khas PDRM dalam mendapatkan data perisikan musuh adalah dengan cara menterjemahkan dokumen serta surat rahsia yang ditemui pada anggota komunis yang mati dibunuh ataupun ditangkap ketika operasi Cari dan Musnah yang dijalankan secara bersepadu oleh pasukan keselamatan. Pada ketika Darurat 1968-1989, Pasukan Cawangan Khas PDRM telah bekerjasama rapat dengan Jabatan Perang Psikologi yang diketuai oleh C.C. Too yang berpengalaman luas dalam mentafsir dokumen PKM sejak Darurat 1948-1960. Kebanyakan dokumen yang ditemui daripada anggota komunis ditulis dalam tulisan bahasa Cina yang turut mempunyai singkatan rahsia. Kebiasaannya, anggota musuh yang menyerah diri (SEP) akan memberi kerjasama dalam usaha mentafsirkan makna informasi sebenar yang tertulis dalam dokumen yang telah berjaya ditemui. Lihat Lim Cheng Leng, The Story of a Psy-Warrior: Tan Sri Dr. C. C. Too", Batu Caves: Terbitan Persendirian, 2000, hlm. 133. Ramlah Adam, Pahlawan Tegar Merdeka, hlm. 34.

69 Mohd Reduan Haji Asli, Pemberontakan Bersenjata Komunis, hlm. 135-136.

70 A.V. Navaratnam, The Spear and The Kerambit, hlm. 92-93.

71 Pada 1 November 1974, Menteri Keselamatan Dalam Negeri, Tan Sri Ghazali Shafie telah membuat pengunguman di media massa berkenaan perpecahan PKM kepada tiga kumpulan iaitu PKM Asal yang diketuai oleh Chin Peng, PKM Kumpulan Revolusi yang diketuai oleh Wong Chung Sing, dan PKM Marxist-Leninist yang diketuai oleh Cheong Chin Mun. Perpecahan tersebut menyebabkan perjuangan PKM mula dilihat terarah kepada bibit-bibit perpecahan, sekali gus melemahkan perjuangan serta sokongan terhadap perjuangan komunis. Lihat Lim Yoon Lin, "Malaysia: The New Mood", dalam Southeast Asian Affairs 1976, Singapura: ISEAS, 1976, hlm. 215.

72 Lihat "China to Continue Backing the CPM", The Star, 11 Ogos 1981.

73 Parti Komunis Thailand telah menamatkan perjuangan bersenjata dengan menyerah diri kepada kerajaan Thailand pada tahun 1981. Lihat Ramlah Adam, Pahlawan Tegar Merdeka, hlm. 58.

$74 \quad$ Temu bual bersama Prof. Madya Dr. Kumar Ramakrishna, 16 Mac 2015.

75 Sharom Hashim, Tentera Darat Menentang Insurgensi Komunis 1968-1989, hlm. 175. 